\title{
The effect of internal teat sealant products (Teatseal and Orbeseal) on intramammary infection, clinical mastitis, and somatic cell counts in lactating dairy cows: A meta-analysis
}

\author{
A. R. Rabiee ${ }^{1}$ and I. J. Lean \\ SBScibus, PO Box 660, Camden 2570, New South Wales, Australia
}

\begin{abstract}
The objective of this study was to assess the efficacy of internal teat sealant products containing bismuth subnitrate (Teatseal and Orbeseal; Pfizer Animal Health, West Ryde, Australia) when used alone, or in the presence of antibiotic dry cow therapy (ADCT), before or at drying off on the incidence of new intramammary infections (IMI), clinical mastitis, and milk somatic cell count (SCC) during lactation. The literature search identified 18 English-language publications on the use of Teatseal in dairy cattle. A total of 12 studies with 17 subtrials or comparisons including 13 positive control subtrials (internal teat sealant and ADCT vs. $\mathrm{ADCT}$ ) and 4 negative control subtrials (internal teat sealant vs. untreated) examining IMI were included in the analysis. Internal teat sealants, alone or in the presence of $\mathrm{ADCT}$, reduced the risk of acquiring new IMI after calving by $25 \%$ [risk ratio $(\mathrm{RR})=0.75 ; 95 \%$ confidence interval (CI): 0.67 to 0.83$]$. Internal teat sealants reduced the risk of IMI by $73 \%$ compared with untreated cows $(\mathrm{RR}=0.27 ; 95 \%$ CI: 0.13 to 0.55$)$. The results of both meta-analyses of IMI, with positive and negative controls, were heterogeneous $\left[I^{2}\right.$ (a statistic that describes the proportion of total variation in study effect estimates that is due to heterogeneity) = 65.4 and $92.1 \%]$. No farm or cow factors studied significantly contributed to the heterogeneity of the results. A total of 16 studies (21 subtrials), including 14 positive control subtrials and 7 negative control subtrials, examining clinical mastitis were included in the analysis. Internal teat sealants alone and in the presence of ADCT reduced the risk of clinical mastitis after calving in lactating cows by $29 \%(\mathrm{RR}=0.71 ; 95 \% \mathrm{CI}: 0.62$ to 0.82 ), and $48 \%$ ( $R R=0.52 ; 95 \%$ CI: 0.37 to 0.75$)$, respectively. The results of the meta-analysis on clinical mastitis with positive controls were homogeneous $\left(I^{2}\right.$ $=33.6 \%$ ), whereas the results of studies with negative controls were heterogeneous $\left(I^{2}=60.4 \%\right)$. No farm or
\end{abstract}

Received January 1, 2013.

Accepted July 16, 2013.

${ }^{1}$ Corresponding author: ahmadr215@hotmail.com cow factors studied that had sufficient data to evaluate significantly contributed to the heterogeneity of the results. The estimated linear score (LS) of milk SCC after calving in published studies $(\mathrm{n}=3)$ and for studies that provided raw data $(\mathrm{n}=2)$, was significantly lower for cattle treated with internal teat sealants and ADCT in 3 studies than for cattle treated with internal teat sealants only. The estimated LS of pooled raw data of 3 studies from 32 herds showed that the LS of cows treated with internal teat sealant and ADCT was not significantly different than those treated with ADCT only. This study found that the application of internal teat sealants in the presence of ADCT or the use of internal teat sealants alone at dry off significantly reduced the incidence of IMI and clinical mastitis in lactating dairy cows compared with respective control groups. Further studies are needed to investigate the effect of internal teat sealants on postpartum milk SCC in lactating dairy cows.

Key words: antibiotic dry cow therapy, mastitis, meta-analysis, Teatseal

\section{INTRODUCTION}

Clinical and subclinical mastitis are major concerns for dairy producers and cause significant economic losses to the dairy industry. The losses include antibiotic treatment, lower milk yield, decreased fertility, and increased culling or death (Bradley, 2002). Although environmental and host factors are critical to the pathogenesis of mastitis, more than 137 different organisms have been identified as causes of clinical mastitis (Watts, 1988). This diversity of agents is reflected in treatment difficulties and limits the efficacy of prevention programs. Interventions that provide means of reducing the risk of infection and the sequelae to infection, such as elevated SCC, independent of causal organisms, are of great potential benefit.

Treatment of cows with long-acting antibiotics at dry off has been an important element of therapeutic and preventive measures in dairy farms (Bramley and Dodd, 1984). Dry cow therapy has been used successfully for 
the treatment of subclinical mastitis at drying off and to protect the udder against new infections during the early dry period (Browning et al., 1990; Williamson et al., 1995). However, milk loss as a result of withholding periods and concerns over the use of antibiotics that may contribute to an increased risk of antibiotic residues and bacterial resistance (WHO, 1994; Berry and Hillerton, 2002b; Oliver and Murinda, 2012; Ruegg, 2012) are matters that suggest the need for alternate approaches to mastitis control.

The use of internal teat sealants as a preventive measure provides an alternate approach to traditional antibiotic programs. The use of internal teat sealants at drying off mimics the physiological mechanisms that close the teat canal (Meaney, 1977). After drying off, a keratin plug forms naturally in the teat canal and acts as an important defense mechanism against IMI. However, the rate of closure of teat canal varies among cows, and it has been suggested that $50 \%$ of teats may still be open $10 \mathrm{~d}$ after drying off (Williamson et al., 1995). Methods of achieving an artificial closure have been examined for the prevention of IMI during the past 30 yr (Meaney, 1977; Williamson et al., 1995; Woolford et al., 1998). A new teat sealant containing bismuth subnitrate was developed by Meaney (1977), who showed that this was effective at preventing new dry period infections in an artificial challenge study. A commercial form of a bismuth subnitrate-based product with the presence of short-acting antibiotic was further developed in Ireland (Osmonds Teat Seal; Cross Vetpharm Group Ltd., Dublin, Ireland). Subsequently, Woolford et al. (1998) experimented with a reformulated version of the teat sealant (Teatseal; Bimeda Ltd., Auckland, New Zealand) to assess its potential for the prevention of new IMI and clinical mastitis during the dry period and subsequent lactation.

Both challenge (Meaney, 1977) and field (Woolford et al., 1998) studies reported a significant reduction in the incidence of IMI and clinical mastitis in cows treated with internal teat sealant products containing bismuth subnitrate and in the presence of antibiotic dry cow therapy (ADCT) during dry off and lactation (Woolford et al., 1998). Similar studies in the United Kingdom (Huxley et al., 2002), Australia (Runciman et al., 2010), New Zealand (Parker et al., 2007, 2008; Laven and Lawrence, 2008), United States (Godden et al., 2003; Cook et al., 2005), and Canada (Sanford et al., 2006b; Baillargeon and LeBlanc, 2010) demonstrated that the use of internal teat sealants at dry off can be effective in preventing IMI or new IMI and clinical mastitis in the subsequent lactation. Crispie et al. (2004) stated that if internal teat sealants are not used hygienically and according to the manufacturer's instructions, this could lead to mastitis. Therefore, the incorporation of antibiotics into internal teat sealants may prevent inadvertent contamination during infusion and improves product safety.

The objectives of this study were to assess the efficacy of an internal teat sealant containing bismuth subnitrate, sold as Orbeseal and Teatseal (Pfizer Animal Health, West Ryde, Australia), when used alone or in the presence of ADCT before or at drying off on the incidence of the cumulative number of new IMI and clinical mastitis cases from the time of dry off to 100 to $150 \mathrm{~d}$ of lactation, and milk SCC in a period from calving to the first 3 wk of lactation. The term internal teat sealant refers to Orbeseal and Teatseal throughout this paper.

\section{MATERIALS AND METHODS}

\section{Literature Search}

The literature search used PubMed (http://www. ncbi.nlm.nih.gov/pubmed), Google Scholar (http:// scholar.google.com/), ScienceDirect (http://www. sciencedirect.com/), and CAB (http://www.cabi.org), contact with workers in the field, records of Pfizer Animal Health, and investigation of references in papers that were identified. The search strategy was to identify papers that contained data on prospective, randomized, controlled experiments examining effects of internal teat sealants, either alone or in the presence of ADCT on the incidence of new IMI and clinical mastitis during the dry period and lactation. Papers identified included 18 English-language publications on the use of internal teat sealants (Teatseal Bimeda, NZ; and Teatseal and Orbeseal, Pfizer Animal Health) in dairy cattle.

The following key words were used in different combinations for our search: internal teat sealant, teat sealer, Teat seal, Teatseal, Orbeseal, intramammary infection, clinical mastitis, postpartum milk SCC, subclinical mastitis, cattle, and cow. The most commonly reported outcomes were IMI and clinical mastitis during the lactation. The definitions used in these studies are listed in Appendix Table A1. In almost all cases, clinical mastitis was diagnosed by dairy managers. Subsequently milk samples were collected by the farm staff or study personnel for bacteriological examination.

\section{Inclusion and Exclusion Criteria}

Studies were included or excluded based on criteria developed by the authors. Quality assessment criteria included randomization of study groups and comparability of treatment groups at entry to each trial. Experiments were included in the analysis if they reported that the cattle used were lactating dairy cows and they 
reported the data required on IMI and clinical mastitis (i.e., number of cases in each group) to determine the relative risk. Only 3 studies (Godden et al., 2003; Baillargeon and LeBlanc, 2010; Runciman et al., 2010) reported measures of milk SCC [i.e., linear score (LS) of SCC]. We were also able to obtain the raw data for milk SCC from 4 investigators.

A total of 21 studies and comparisons were excluded from the analysis. Studies that failed to meet the selection criteria included reviews $(n=2)$, experimentally infected cows $(\mathrm{n}=6)$, studies that compared internal teat sealant with lacticin 3147 or a combination of teat sealant with lacticin $3147(\mathrm{n}=3)$, and studies published in non-English journals $(\mathrm{n}=6)$. Comparisons and trials within studies that treated cows systemically with antibiotics (Parker et al., 2008; experiments 1, 3, and 4) or when internal teat sealant was used in both treatment and control groups (Bradley et al., 2010; experiment 2) were also excluded from analysis.

\section{Data Extraction}

A total of 18 field studies with 22 IMI and 27 clinical mastitis subtrials and comparisons were reviewed. Of this, 17 IMI and 21 clinical mastitis subtrials and comparisons met the eligibility criteria for meta-analysis. Data recorded included authors, year of publication, country, number of farms, breed, parity, unit of observation for treatment allocation and analysis, DIM, dry period, type of ADCT used, diagnostic methods of IMI and clinical mastitis, and farming systems. A summary of studies and variables that were measured is provided in Table 1 and Appendix Table A2). Information on the type and name of ADCT and teat sealant, number of cows and quarters, and number of cows with IMI and clinical mastitis in the control and treatment groups is provided in Table 2.

\section{Statistical Analysis}

A meta-analysis was conducted on the incidence of IMI and clinical mastitis using Stata (Intercooled Stata v.12; StataCorp, 2011). Fixed effect (Mantel and Haenszel, 1959) and random effects (DerSimonian and Laird, 1986) models were used to assess the efficacy of internal treat sealants on the risk of IMI and clinical mastitis. In this study, risk ratio (RR) is the risk of IMI or clinical mastitis in cows that were treated with internal teat sealant commercial products or in the presence of ADCT (e.g., cloxacillin or cephalonium) compared with cows in control groups: either negative controls (untreated controls) or positive controls that were treated with ADCT. A total of 17 IMI and 21 clinical mastitis trials and comparisons were eligible for the meta-analyses. Studies conducted to assess the effect of therapeutic dry cow treatments on mastitis in dairy cattle needed to have adequate randomization among mammary quarters or cows.

The statistical methods of meta-analytic procedures that were used in this paper have been previously published (Lean et al., 2012; Rabiee et al., 2012). Briefly, a fixed-effect model is based on the assumption that every study evaluates a common treatment effect. Specifically, the fixed-effect assumption means that the hypothetical effect of treatment is the same in all studies. The summary treatment effect estimate resulting from this method of meta-analysis is a fixed treatment effect, and the confidence interval provided describes how certain we are about the pooled estimate.

A Mantel-Haenszel risk ratio $\left(\mathrm{RR}_{\mathrm{M}-\mathrm{H}}\right)$ is calculated using the following formula (Rothman, 1986), which is generated from a contingency $2 \times 2$ table:

$$
\mathrm{RR}_{\mathrm{M}-\mathrm{H}}=\frac{\sum\left(a_{j} N_{0 j} / T_{j}\right)}{\sum\left(b_{j} N_{1 j} / T_{j}\right)},
$$

where $a_{j}$ is the number of IMI or clinical mastitis cases (cow or quarter) in the treatment group for trial $j, b_{j}$ is the number of IMI or clinical mastitis cases (cow or quarter) in the control group for trial $j$, and $N_{0 j}$ and $N_{1 j}$ represent the number of cows in the treated and control groups, respectively. The numerator and denominator are summed over $j$, the number of trials.

The random effects model assumes that the true treatment effects in individual studies may differ from each other. The true treatment difference in each trial is also assumed to be a realization of the random variable. The random variable is usually assumed to be normally distributed. The standard error of each trial estimate is increased and reflects the within- and between-trial variation. A pooled DerSimonian and Laird (1986) risk ratio $\left(R_{D+L}\right)$ is calculated with the following formula:

$$
\mathrm{RR}_{\mathrm{D}+\mathrm{L}}=\frac{\sum\left(W_{i} \mathrm{RR}_{i}\right)}{\sum\left(W_{i}\right)} ;
$$

$95 \% \mathrm{CI}=\theta-[1.96 \times \mathrm{SE}(\theta)]$ to $\theta+[1.96 \times \mathrm{SE}(\theta)] ;$

$$
\text { Predictive interval }=t(\mathrm{df}) \times \sqrt{\left(\mathrm{SE}^{2}+\tau^{2}\right)},
$$

where $W_{i}$ is the weight (inverse variance) of individual studies and $\mathrm{RR}_{i}$ is the risk ratio of each subtrial or comparison $(i)$. The $95 \%$ confidence interval for the overall estimate $\theta$ was estimated using Equation 2b, 
Table 1. Studies that investigated the effect of teat sealant products (Teatseal and Orbeseal; Pfizer Animal Health, West Ryde, Australia) on the incidence of IMI and clinical mastitis during the dry period and after calving

\begin{tabular}{|c|c|c|c|c|c|c|c|}
\hline Study & Breed & Parity & $\begin{array}{l}\text { Unit of } \\
\text { treatment }\end{array}$ & $\begin{array}{l}\text { Unit of } \\
\text { analysis }\end{array}$ & DIM & Dry period $^{1}(\mathrm{~d})$ & SCC at enrollment \\
\hline Bradley et al. (2010) & $\begin{array}{l}\text { Guernsey } \\
\text { Holstein-Friesian }\end{array}$ & Multiparous & $\begin{array}{l}\text { Quarter, } \\
\text { within cow }\end{array}$ & Quarter & 100 & $\begin{array}{l}61 \text { (uninfected); } \\
70 \text { (infected) }\end{array}$ & $\begin{array}{l}\text { Uninfected: clinical } \\
\text { history and SCC } \\
<200 \text { of the last } 3 \mathrm{mo} \text {; } \\
\text { infected: } \mathrm{SCC}>200\end{array}$ \\
\hline Bradley et al. (2011) & Holstein-Friesian & Multiparous & $\begin{array}{l}\text { Cow, quarters } \\
\text { between cows }\end{array}$ & Quarter & 100 & $\begin{array}{l}62.3 \text { (CDC); } \\
64.3 \text { (COMBO); } \\
62.7 \text { (OEDC) }\end{array}$ & Bulk milk SCC <300 \\
\hline Runciman et al. (2010) & - & Multiparous & $\begin{array}{l}\text { Cow, quarters } \\
\text { between cows }\end{array}$ & Cow & $98.5 ; 98.6$ & $63.6 ; 64.4$ & $\mathrm{SCC}<250 ;$ SCC $>250$ \\
\hline Woolford et al. (1998) & $\begin{array}{l}\text { Holstein-Friesian } \\
\text { and Friesian } \times \text { Jersey }\end{array}$ & $\begin{array}{l}\text { Multiparous } \\
\text { and primiparous }\end{array}$ & $\begin{array}{l}\text { Quarter, } \\
\text { within cow }\end{array}$ & Quarter & 150 & & $\mathrm{SCC}<200$ \\
\hline Godden et al. (2003) & & Multiparous & $\begin{array}{l}\text { Quarter, } \\
\text { within cow }\end{array}$ & Quarter & 60 & 28 to 100 & \\
\hline Berry and Hillerton (2002a) & & & $\begin{array}{l}\text { Cow, quarters } \\
\text { between cows }\end{array}$ & $\begin{array}{l}\text { Quarter } \\
\text { and cow }\end{array}$ & 100 & & $\mathrm{SCC}<200$ \\
\hline Berry et al. (2003) & & & $\begin{array}{l}\text { Cow, quarters } \\
\text { between cows }\end{array}$ & $\begin{array}{l}\text { Quarter } \\
\text { and cow }\end{array}$ & 100 & 56 to 70 & \\
\hline Newton et al. (2008) & & & $\begin{array}{l}\text { Quarter, } \\
\text { within cow }\end{array}$ & Quarter & 100 & & $\mathrm{SCC}>200$ \\
\hline Cook et al. (2005) & & & $\begin{array}{l}\text { Cow, quarters } \\
\text { between cows }\end{array}$ & Quarter & 100 & & \\
\hline Huxley et al. (2002) & & & $\begin{array}{l}\text { Cow, quarters } \\
\text { between cows }\end{array}$ & $\begin{array}{l}\text { Quarter } \\
\text { and cow }\end{array}$ & 100 & $>51$ & $\begin{array}{l}\text { Herd selection: bulk } \\
\text { SCC < 200; cow } \\
\text { selection: } \mathrm{SCC}<200\end{array}$ \\
\hline Laven and Lawrence (2008) & $\begin{array}{l}\text { Friesian and Friesian } \\
\times \text { Jersey }\end{array}$ & & Cow and heifer & $\begin{array}{l}\text { Cow } \\
\text { and heifer }\end{array}$ & 85 & & $\mathrm{SCC}>150 ; \mathrm{SCC}<150$ \\
\hline Parker et al. (2007) & $\begin{array}{l}\text { Friesian, cross-bred, } \\
\text { and Jersey }\end{array}$ & Primiparous & $\begin{array}{l}\text { Quarter, } \\
\text { within heifer }\end{array}$ & Heifer & 14 & & \\
\hline Parker et al. (2008) & & Primiparous & Heifer & Heifer & 14 & & \\
\hline Sanford et al. (2006b) & Holstein-Friesian & Multiparous & $\begin{array}{l}\text { Quarter, } \\
\text { within cow }\end{array}$ & Quarter & 60 & 30 to 90 & \\
\hline Izak et al. (2011; abstract) & & Multiparous & Cow & Cow & 100 & At least $45 \mathrm{~d}$ & $\begin{array}{l}\mathrm{SCC}<250 \text { and no } \\
\text { clinical mastitis }\end{array}$ \\
\hline Baillargeon and LeBlanc (2010) & Holstein-Friesian & Multiparous & Cow & Cow & 105 & $\begin{array}{l}28 \text { to } 120 \mathrm{~d} \\
\text { (mean: } 62)\end{array}$ & \\
\hline
\end{tabular}

${ }^{1} \mathrm{CDC}=$ cephalosporin cefquinome; COMBO = combination treatment comprising narrow-spectrum cloxacillin and an internal teat sealant; OEDC = narrow-spectrum antibiotic treatment comprising cloxacillin alone. 
Table 2. Number of herds, animals and quarters, products used in control and treatment groups, and number of cases with IMI and clinical mastitis

\begin{tabular}{|c|c|c|c|c|c|c|c|c|c|c|}
\hline \multirow[b]{2}{*}{ Study } & \multirow{2}{*}{$\begin{array}{l}\text { No. of } \\
\text { herds }\end{array}$} & \multirow{2}{*}{$\begin{array}{l}\text { No. of } \\
\text { animals }\end{array}$} & \multirow{2}{*}{$\begin{array}{l}\text { No. of } \\
\text { quarters }\end{array}$} & \multirow[b]{2}{*}{ Criteria } & \multirow[b]{2}{*}{ Control } & \multirow[b]{2}{*}{ Treatment } & \multicolumn{2}{|c|}{$\begin{array}{l}\text { IMI at quarter } \\
\text { or cow levels }\end{array}$} & \multicolumn{2}{|c|}{$\begin{array}{l}\text { Clinical mastitis } \\
\text { after calving } \\
\text { (quarter/cows) }^{2}\end{array}$} \\
\hline & & & & & & & Control & Treatment & Control & Treatment \\
\hline \multirow[t]{2}{*}{ Bradley et al. (2010) } & 6 & 419 & 1,604 & $\begin{array}{l}\text { High SCC } \\
\text { infected } \\
(>250)\end{array}$ & $\begin{array}{l}250 \mathrm{mg} \text { of } \\
\text { cephalonium }^{3}\end{array}$ & $\begin{array}{l}250 \mathrm{mg} \text { of cephalonium } \\
+ \text { Orbeseal }^{4}\end{array}$ & $330 / 830$ & $271 / 831$ & $84 / 862$ & $59 / 862$ \\
\hline & & 391 & 1,632 & $\begin{array}{l}\text { Low SCC } \\
\text { uninfected } \\
(<250)\end{array}$ & $\begin{array}{l}250 \mathrm{mg} \text { of } \\
\text { cephalonium }+ \\
\text { Orbeseal }\end{array}$ & Orbeseal & $256 / 779$ & $288 / 777$ & $41 / 816$ & $44 / 816$ \\
\hline \multirow[t]{2}{*}{ Bradley et al. (2011) } & 8 & 305 & 1,220 & $\begin{array}{l}\text { Bulk milk SCC } \\
<300\end{array}$ & $\begin{array}{l}150 \mathrm{mg} \text { of } \\
\text { cephalosporin } \\
\text { cefquinome }^{5}\end{array}$ & $\begin{array}{l}600 \mathrm{mg} \text { of cloxacillin }{ }^{6}+ \\
\text { Orbeseal }\end{array}$ & $207 / 577$ & $187 / 613$ & $25 / 151$ & $31 / 154$ \\
\hline & & 306 & 1,236 & & $600 \mathrm{mg}$ of cloxacillin & $\begin{array}{l}600 \mathrm{mg} \text { of cloxacillin }+ \\
\text { Orbeseal }\end{array}$ & $232 / 588$ & $187 / 613$ & $37 / 155$ & $31 / 154$ \\
\hline Runciman et al. $(2010)^{7}$ & 6 & 886 & & $\mathrm{SSC}>250$ & $600 \mathrm{mg}$ of cloxacillin & $\begin{array}{l}\text { Teatseal }^{8}+600 \mathrm{mg} \text { of } \\
\text { cloxacillin }\end{array}$ & $156 / 2,147$ & $79 / 2,069$ & $129 / 299$ & $81 / 265$ \\
\hline \multirow[t]{4}{*}{ Woolford et al. (1998) } & 3 & $\begin{array}{r}1,127 \\
528\end{array}$ & 1,033 & $\mathrm{SSC}<250$ & $\begin{array}{l}600 \mathrm{mg} \text { of cloxacillin } \\
\text { Negative control }\end{array}$ & $\begin{array}{l}\text { Teatseal } \\
\text { Teatseal }^{9}\end{array}$ & $85 / 528$ & $13 / 505$ & $\begin{array}{l}82 / 331 \\
22 / 143\end{array}$ & $\begin{array}{r}54 / 312 \\
6 / 121\end{array}$ \\
\hline & & & & & $\begin{array}{l}250 \mathrm{mg} \text { of } \\
\text { cephalonium }\end{array}$ & Teatseal & $14 / 528$ & $13 / 505$ & $10 / 143$ & $6 / 121$ \\
\hline & & & & & Negative control & $\begin{array}{l}600 \mathrm{mg} \text { of cloxacillin } \\
\text { Teatseal + }\end{array}$ & $85 / 528$ & $10 / 505$ & $22 / 143$ & $11 / 121$ \\
\hline & & & & & $\begin{array}{l}250 \mathrm{mg} \text { of } \\
\text { cephalonium }\end{array}$ & $\begin{array}{l}600 \mathrm{mg} \text { of cloxacillin } \\
\text { Teatseal }\end{array}$ & $14 / 528$ & $10 / 505$ & $10 / 143$ & $11 / 121$ \\
\hline \multirow[t]{4}{*}{ Godden et al. (2003) } & 2 & 419 & & Dry period & $600 \mathrm{mg}$ of cloxacillin & $\begin{array}{l}600 \mathrm{mg} \text { of cloxacillin }+ \\
\text { Orbeseal }\end{array}$ & & & & \\
\hline & & & & 1 to 3 DIM & $600 \mathrm{mg}$ of cloxacillin & $\begin{array}{l}600 \mathrm{mg} \text { of cloxacillin }+ \\
\text { Orbeseal }\end{array}$ & $236 / 812$ & $187 / 821$ & & \\
\hline & & & & 6 and 8 DIM & $600 \mathrm{mg}$ of cloxacillin & $\begin{array}{l}600 \mathrm{mg} \text { of cloxacillin }+ \\
\text { Orbeseal }\end{array}$ & $210 / 811$ & $167 / 809$ & & \\
\hline & & & & $60 \mathrm{DIM}$ & $600 \mathrm{mg}$ of cloxacillin & $\begin{array}{l}600 \mathrm{mg} \text { of cloxacillin }+ \\
\text { Orbeseal }\end{array}$ & & & $66 / 862$ & $51 / 862$ \\
\hline \multirow[t]{2}{*}{ Berry and Hillerton (2002a) } & 7 & 401 & 1,596 & Dry period & Negative control & Osmonds Teat Seal ${ }^{10}$ & & & & \\
\hline & & 398 & 1,583 & At calving & Negative control & Osmonds Teat Seal ${ }^{10}$ & & & $\begin{array}{l}93 / 799 \\
62 / 201\end{array}$ & $\begin{array}{l}27 / 784 \\
21 / 197\end{array}$ \\
\hline Berry and Hillerton (2007) & 1 & 1,127 & & At calving & Cephalonium & $\begin{array}{l}\text { Cephalonium + } \\
\text { Orbeseal }\end{array}$ & $39 / 531$ & $22 / 596$ & $15 / 133$ & $4 / 150$ \\
\hline Newton et al. (2008) & 10 & 283 & $\begin{array}{l}\text { Total: } 1,924 ; \\
\text { enrolled: } 313\end{array}$ & After calving & $600 \mathrm{mg}$ of cloxacillin & $\begin{array}{l}600 \mathrm{mg} \text { of cloxacillin }+ \\
\text { Orbeseal }\end{array}$ & $181 / 566$ & $152 / 566$ & $50 / 141$ & $23 / 142$ \\
\hline Cook et al. (2005) & 3 & 528 & 2,112 & 1-3 DIM & $\begin{array}{l}\text { Penicillin- } \\
\text { dihydrostreptomycin }^{11}\end{array}$ & $\begin{array}{l}\text { Orbeseal penicillin- } \\
\text { dihydrostreptomycin }\end{array}$ & $160 / 971$ & $81 / 1,009$ & & \\
\hline Huxley et al. (2002) & 16 & $\begin{array}{l}\text { IMI: } 467 ; \\
\text { mastitis: } 479\end{array}$ & 2,016 & After calving & $\begin{array}{l}250 \mathrm{mg} \text { of } \\
\text { cephalonium }\end{array}$ & Teatseal & $369 / 940$ & $321 / 923$ & $31 / 242$ & $25 / 237$ \\
\hline \multirow[t]{3}{*}{ Laven and Lawrence (2008) } & 1 & 249 Infected & & $\begin{array}{l}\text { After calving } \\
\text { (first } 11 \mathrm{wk} \\
\text { after calving) }\end{array}$ & $600 \mathrm{mg}$ of cloxacillin & Teatseal & & & $17 / 114$ & $11 / 135$ \\
\hline & & 217 Noninfected & & & Negative control & Teatseal & & & $11 / 108$ & $7 / 109$ \\
\hline & & 206 Heifers & & & Negative control & Teatseal & & & 18/102 & $6 / 104$ \\
\hline Parker et al. (2007) & 5 & 255 Heifers & 1,020 & $\begin{array}{l}\text { IMI within } 4 \\
\text { DIM }\end{array}$ & Negative control & Teatseal & $66 / 505$ & $49 / 501$ & $34 / 501$ & $21 / 501$ \\
\hline
\end{tabular}




\begin{tabular}{|c|c|c|c|c|c|c|c|c|c|c|}
\hline \multirow[b]{2}{*}{ Study } & \multirow{2}{*}{$\begin{array}{l}\text { No. of } \\
\text { herds }\end{array}$} & \multirow{2}{*}{$\begin{array}{l}\text { No. of } \\
\text { animals }\end{array}$} & \multirow{2}{*}{$\begin{array}{l}\text { No. of } \\
\text { quarters }\end{array}$} & \multirow[b]{2}{*}{ Criteria } & \multirow[b]{2}{*}{ Control } & \multirow[b]{2}{*}{ Treatment } & \multicolumn{2}{|c|}{$\begin{array}{l}\text { IMI at quarter } \\
\text { or cow levels }{ }^{1}\end{array}$} & \multicolumn{2}{|c|}{$\begin{array}{l}\text { Clinical mastitis } \\
\text { after calving } \\
\text { (quarter/cows) }^{2}\end{array}$} \\
\hline & & & & & & & Control & Treatment & Control & Treatment \\
\hline \multirow[t]{4}{*}{ Parker et al. (2008) } & \multirow[t]{4}{*}{30} & \multirow[t]{4}{*}{1,067} & \multirow[t]{4}{*}{4,146} & \multirow[t]{4}{*}{$\begin{array}{l}\text { IMI within } 5 \\
\text { DIM }\end{array}$} & Tylosin $^{12}$ (i.m.) & Teatseal & $259 / 1,028$ & $77 / 1,028$ & $74 / 268$ & $60 / 268$ \\
\hline & & & & & Negative control & Teatseal & $255 / 1,036$ & $77 / 1,028$ & $69 / 265$ & $60 / 268$ \\
\hline & & & & & Tylosin (i.m.) & $\begin{array}{l}\text { Tylosin (i.m.) + } \\
\text { Teatseal }\end{array}$ & $259 / 1,028$ & $97 / 1,052$ & $74 / 268$ & $104 / 266$ \\
\hline & & & & & Negative control & $\begin{array}{l}\text { Tylosin (i.m.) + } \\
\text { Teatseal }\end{array}$ & $255 / 1,036$ & $97 / 1,052$ & $69 / 268$ & $104 / 266$ \\
\hline \multirow[t]{2}{*}{ Sanford et al. (2006b) } & 16 & $\begin{array}{l}408 \text { cows with } \\
\text { negative milk } \\
\text { culture }\end{array}$ & 1,562 & \multirow{4}{*}{$\begin{array}{l}\text { Negative milk } \\
\text { culture } 14 \mathrm{~d} \\
\text { before dry off } \\
\text { Positive milk } \\
\text { culture } 14 \mathrm{~d} \\
\text { before dry off } \\
\text { SCC <250 } \\
\text { and with no } \\
\text { previous IMI }\end{array}$} & $500 \mathrm{mg}$ of cloxacillin & Orbeseal & $54 / 788$ & $48 / 774$ & & \\
\hline & & $\begin{array}{l}326 \text { cows with } \\
\text { positive milk } \\
\text { culture }\end{array}$ & 1,209 & & $500 \mathrm{mg}$ of cloxacillin & $\begin{array}{l}500 \mathrm{mg} \text { of cloxacillin }+ \\
\text { Orbeseal }\end{array}$ & $49 / 605$ & $28 / 604$ & & \\
\hline Izak et al. (2011) & 2 & 78 & & & $600 \mathrm{mg}$ of cloxacillin & Teatseal & & & $2 / 36$ & $10 / 42$ \\
\hline $\begin{array}{l}\text { Baillargeon and LeBlanc } \\
(2010)\end{array}$ & 12 & 1,334 & & & $\begin{array}{l}\text { Antimicrobial dry- } \\
\text { cow therapy (ADCT) }\end{array}$ & Orbeseal + ADCT & & & $125 / 669$ & $97 / 665$ \\
\hline
\end{tabular}

${ }^{1}$ New IMI after calving includes number of acquired IMI during the dry period and at or after calving and diagnosed after calving.

${ }^{2}$ Number of clinical quarters over total number of quarters; number of clinical quarters over total number of cows; number of clinical cows over total number of cows.

${ }^{3}$ Cepravin Dry Cow (Intervet Schering-Plough Animal Health, Milton Keynes, UK).

${ }^{4}$ Orbeseal (Pfizer Animal Health, Sandwich, UK).

${ }^{5}$ Cephaguard Dry Cow (Virbac Ltd., Bury St. Edmunds, UK).

${ }^{6}$ Orbenin Extra Dry Cow (Pfizer Animal Health, Sandwich, UK).

${ }^{7}$ Environmental pathogens.

${ }^{8}$ Teatseal (Pfizer Animal Health).

${ }^{9}$ Teatseal [Bimeda (NZ) Ltd., Auckland, New Zealand].

${ }^{10}$ Osmonds Teat Seal (Cross Vetpharm Group, Tallaght, Dublin, Ireland).

${ }^{11}$ Quartermaster (Pfizer Animal Health).

${ }^{12}$ Tylan (Elanco Animal Health, Manukau City, New Zealand). 
Table 3. Relative risk and probability of IMI and clinical mastitis in dairy cows treated with internal teat sealants (Teatseal and Orbeseal; Pfizer Animal Health, West Ryde, Australia) alone or in the presence of antibiotic dry cow treatments (ADCT), number needed to treat (NNT), and heterogeneity among trials

\begin{tabular}{|c|c|c|c|c|c|c|c|}
\hline \multirow[b]{2}{*}{ Variable } & \multirow[b]{2}{*}{$\begin{array}{l}\text { Subgroup } \\
\text { (no. of comparisons) }\end{array}$} & \multirow{2}{*}{$\begin{array}{c}\text { Relative risk and } 95 \% \text { CI } \\
\text { Random effect } \\
\text { (DerSimonian and Laird, } \\
1986)\end{array}$} & \multirow[b]{2}{*}{$P$-value } & \multirow[b]{2}{*}{ NNT } & \multicolumn{3}{|c|}{ Heterogeneity $^{1}$} \\
\hline & & & & & $\begin{array}{l}\text { Q statistics } \\
\text { (chi-squared) }\end{array}$ & $I^{2}[\%(95 \% \mathrm{CI})]$ & $P$-value \\
\hline \multirow[t]{2}{*}{ IMI } & Positive control $(\mathrm{n}=13)$ & $0.75(0.67,0.83)$ & $<0.001$ & 20 & 34.71 & $65.4(38,81)$ & $<0.001$ \\
\hline & Negative control $(\mathrm{n}=4)$ & $0.27(0.13,0.55)$ & $<0.001$ & 7 & 37.79 & $92.1(83,96)$ & $<0.001$ \\
\hline Clinical mastitis & Positive control $(\mathrm{n}=14)$ & $0.71(0.62,0.82)$ & $<0.001$ & 21 & 19.58 & $33.6(0,65)$ & 0.11 \\
\hline
\end{tabular}

${ }^{1} \tilde{I}^{2}=$ a statistic that describes the proportion of total variation in study effect estimates that is due to heterogeneity.

where $\theta$ is the $\log \mathrm{RR}$ and $\mathrm{SE}$ is the standard error of $\log \mathrm{RR}$ (Egger et al., 2001). The confidence interval of the approximate predictive distribution of a future trial was estimated based on the extent of heterogeneity. This incorporated uncertainty in the location and spread of the random effects distribution used Equation $2 \mathrm{c}$, where $t$ is the $t$-distribution with $k-2$ degrees of freedom (where $k$ is the number of experiments), $\mathrm{SE}^{2}$ is the squared standard error, and $\tau^{2}$ is the heterogeneity statistic (Bradburn et al., 1998).

The number needed to treat (NNT) is the number of individuals that need to be treated to expect that 1 case of mastitis would be prevented (http://handbook. cochrane.org/). The NNT is equal to $1 /$ (control group event risk - treatment group event risk) (Bradburn, 2003). The NNT was calculated in this study to provide several cows that needed to be treated with internal teat sealant to prevent 1 additional IMI or clinical case of mastitis after calving in lactating dairy cows is provided in Table 3. The NNT was calculated with Stata using the methods of Bradburn (2003).

\section{Forest Plots}

The effects of internal teat sealant on the risk of IMI and clinical mastitis in lactating dairy cows are provided in the forest plots (Figures 1 and 2). Points to the left of the line at $R R=1$ represent a reduction in the risk of IMI or clinical mastitis, whereas points to the right of the line indicate an increase in the risk of IMI or clinical mastitis. Each square represents the RR for that study or subtrial. The upper and lower limit of the line connected to the square represents the upper and lower $95 \%$ confidence interval for the RR. The size of the square reflects the relative weighting of the study to the overall $\mathrm{RR}$ estimate with larger squares representing greater weight. The dotted vertical line represents the overall $\mathrm{RR}$ estimate. The diamonds at the bottom represent the $95 \%$ confidence interval for the overall estimates of fixed effect (Mantel and Haenszel, 1959) and random effects (DerSimonian and Laird, 1986) models.
The lines that are horizontally stretched on $\mathrm{D}+\mathrm{L}$ diamond shapes are the predicted intervals and represent a conservative estimate of a predicted response to future treatment. The solid vertical line with RR of 1 is provided to indicate no net effect of intervention.

The SCC data for cows after calving in 3 studies (Cook et al., 2005; Sanford et al., 2006b; Baillargeon and LeBlanc, 2010) containing 32 herds were extracted and analyzed to compare the effect of internal teat sealant in the presence of ADCT versus ADCT treatment alone. The LS of postpartum milk SCC were analyzed using a mixed-effects linear model in which treatment, parity, and LS at drying off were the fixed effect terms and herd was the random effects term:

$$
y_{i j}=\beta_{0}+\beta_{1} X_{1 i j}+\beta_{2} X_{2 i j}+\beta_{3} X_{3 i j}+\mu_{j}+\varepsilon_{i j}
$$

where $y_{i j}$ is the response variable (LS in lactation), $\beta_{0}$ (intercept) is the overall mean of LS, and $\beta_{1}$ to $\beta_{3}$ are the fixed-effect coefficients of internal teat sealant, parity, and LS at drying off, respectively. In this model, $X_{1 i j}$ to $X_{3 i j}$ are the fixed-effect terms (internal teat sealant, parity, and LS at drying off), $\mu_{j}$ is the randomeffect of herd, and $\varepsilon_{i j}$ is the residuals (error term). The interaction between internal teat sealant and herd was also examined.

\section{Assessment of Heterogeneity}

Heterogeneity among the estimated RR for studies included in the meta-analysis were assessed using a chi-squared $\left(\chi^{2}\right)$ test of heterogeneity. In this case, the null hypothesis was that the effect of treatment was the same across $j$ trials and the null hypothesis was rejected if the heterogeneity test statistic was greater than a critical value that separated the upper $10 \%$ of a $\chi^{2}$ distribution with $(j-1)$ degrees of freedom. We used an $\alpha$ level of 0.10 because of the relatively poor power of the $\chi^{2}$ test to detect heterogeneity among a small number of experiments (Egger and Davey Smith, 2001). Heterogeneity of results among experiments was 
quantified using the $I^{2}$ statistic (Higgins and Thompson, 2002; Higgins et al., 2003), which describes the proportion of total variation in study effect estimates that is due to heterogeneity.

Higgins and Thompson (2002) developed measures of the impact of heterogeneity in a meta-analysis from mathematical criteria that are independent of the number of studies and the treatment effect metric. The $I^{2}$ is described as a percentage of the total variation that is due to heterogeneity rather than chance:

$$
\begin{gathered}
I^{2}(\%)=\frac{[Q-(k-1)]}{Q} \times 100 ; \\
95 \% \mathrm{UI}=\sqrt{\frac{1}{k-1}[Q \pm 1.96 \sqrt{\operatorname{Var}(Q)}]},
\end{gathered}
$$

where $Q$ is the chi-squared $\left(\chi^{2}\right)$ heterogeneity statistic, $k$ is the number of experiments, and $I^{2}$ was calculated according to Thompson and Sharp (1999) and Higgins et al. (2003). Uncertainty intervals (UI) for $I^{2}$ (dependent on $Q$ and $k$ ) were calculated using the method described by Higgins and Thompson (2002) using Equation 4b. Negative values of $I^{2}$ are equal to zero; consequently, $I^{2}$ lies between 0 and 100\%. A value higher than $50 \%$ may be considered substantial heterogeneity (Higgins et al., 2003).

\section{Meta-Regression}

Meta-regression analyses were used to explore the source of heterogeneity of response using the logarithm of individual RR ( $\log R R$ ) for each experiment as the outcome and the associated standard error as the measure of variance. We have previously described the meta-regression procedures (Lean et al., 2012; Rabiee et al., 2012).

\section{Publication Bias}

No definitive means exists to assess the presence of publication bias in meta-analysis (http://handbook. cochrane.org). Several statistical tests exist for detecting funnel plot asymmetry [for example, the rank correlation test of Begg and Mazumdar (1994) and the linear regression test of Egger et al. (1997)], but these do not have considerable power and are rarely used. Funnel plots can be used visually to demonstrate the presence or absence of small-study effect as publication bias.

A funnel plot (as shown in Figures 3 and 4) is a simple scatter plot of the intervention effect estimates from individual studies against a measure of each study's size or precision. It is commonly presented as a plot of the effect estimates on the horizontal scale, and the measure of variance on the vertical axis. The name funnel plot arises because the precision of the estimated intervention effect increases as the size of the experiment increases. Effect estimates from small experiments will, therefore, scatter more widely at the bottom of the graph, with the spread narrowing among larger experiments. In the absence of bias, the plot should approximately resemble a symmetrical (inverted) funnel. If bias exists (for example, because smaller experiments without statistically significant effects remain unpublished), this will lead to an asymmetrical appearance of the funnel plot, with observations (trials and subtrials) missing from the bottom corners of the graph. In this situation, the effect calculated in a meta-analysis will tend to overestimate the intervention effect (Egger et al., 1997). The more pronounced the asymmetry, the more likely it is that the bias will be substantial. The dashed lines provide the pseudo-confidence intervals for the RR estimates within the funnel plot. The vertical line is where the $R R=1$.

\section{Contour-Enhanced Funnel Plots}

Contour-enhanced funnel plots have been proposed by Peters et al. (2008) to include contour lines corresponding to the statistical significance $(P=0.01,0.05$, and 0.1 ). This approach allows reviewers to differentiate among the trials that are highly significant from trials that are perceived to be missing. The contour-enhanced funnel plots may help to differentiate asymmetry caused by publication bias from that due to other factors. For example, if experiments appear to be missing in areas of statistical nonsignificance, then this adds credence to the possibility that the asymmetry is caused by publication bias. Conversely, if putative missing studies are in areas of higher statistical significance, this suggests that the observed asymmetry may more likely be due to factors other than publication bias.

\section{Milk SCC}

We were able to obtain the raw milk SCC data from 4 investigators (Cook et al., 2005; Sanford et al., 2006b; Parker et al., 2007; Baillargeon and LeBlanc, 2010) and estimated the LS of milk SCC after calving. Data from Parker et al. (2007) were not used in this report because these samples were collected immediately after calving and may have contained colostrum (K. I. Parker, Animal Health Centre, Morrinsville, New Zealand, personal communication). We analyzed data that were provided by Cook et al. (2005) and Sanford et al. (2006b), but not published in the original papers, and estimated the LS of milk SCC after calving for each 
Table 4. Milk SCC (linear score) of cows treated with internal teat sealants (Teatseal and Orbeseal; Pfizer Animal Health, West Ryde, Australia) and antibiotic dry cow treatments (ADCT) during the first 3 wk after calving

\begin{tabular}{|c|c|c|c|c|c|c|c|c|c|}
\hline \multirow[b]{2}{*}{ Study } & \multirow{2}{*}{$\begin{array}{l}\text { Experiment/ } \\
\text { period }\end{array}$} & \multirow[b]{2}{*}{ Source } & \multirow[b]{2}{*}{ DIM } & \multirow[b]{2}{*}{ Control } & \multirow[b]{2}{*}{ Treatment } & \multirow{2}{*}{$\begin{array}{l}\text { Statistical model } \\
\text { and variables } \\
\text { accounted for }\end{array}$} & \multicolumn{2}{|c|}{$\begin{array}{l}\text { Linear score of SCC; no. of cows } \\
(\text { mean } \pm \text { SE })\end{array}$} & \multirow[b]{2}{*}{$P$-value } \\
\hline & & & & & & & Control & Treatment & \\
\hline $\begin{array}{l}\text { Godden et al. (2003; } \\
\text { United States) }\end{array}$ & Period 1 & Paper & $1-3$ & $600 \mathrm{mg}$ of cloxacillin & $\begin{array}{l}600 \mathrm{mg} \text { of cloxacillin } \\
+ \text { Orbeseal }\end{array}$ & $\begin{array}{l}\text { Multivariate linear } \\
\text { regression (PROC } \\
\text { MIXED }^{1} \text {; not } \\
\text { specified) }\end{array}$ & $\mathrm{NA}^{2} ; 5.40 \pm 0.17$ & $\mathrm{NA} ; 5.10 \pm 0.17$ & $<0.001$ \\
\hline $\begin{array}{l}\text { Runciman et al. (2010; } \\
\text { Australia) }\end{array}$ & Period 2 & Paper & $\begin{array}{l}6 \text { and } 8 \\
7\end{array}$ & $600 \mathrm{mg}$ of cloxacillin & $\begin{array}{l}\text { Teatseal }+600 \mathrm{mg} \\
\text { of cloxacillin }\end{array}$ & $\begin{array}{l}\text { Multivariate linear } \\
\text { regression (accounted } \\
\text { for age, milk yield, } \\
\text { SCC in previous } \\
\text { lactation, herd) }\end{array}$ & $\begin{array}{l}\mathrm{NA} ; 3.10 \pm 0.18 \\
\mathrm{NA} ; 4.72 \pm 0.05\end{array}$ & $\begin{array}{l}\mathrm{NA} ; 2.80 \pm 0.18 \\
\mathrm{NA} ; 4.41 \pm 0.05\end{array}$ & $<0.001$ \\
\hline $\begin{array}{l}\text { Baillargeon and LeBlanc } \\
\text { (2010; Canada) }\end{array}$ & & Paper & $>5$ & $\mathrm{ADCT}$ & Orbeseal + ADCT & $\begin{array}{l}\text { Mixed linear } \\
\text { regression [accounted } \\
\text { for parity, season } \\
\text { of calving and herd } \\
\text { (random)] }\end{array}$ & $2.50 \pm 0.18$ & $\begin{array}{l}34 \\
2.44 \pm 0.18\end{array}$ & 0.11 \\
\hline Cook et al. (2005) & & Data & $15-18$ & $\begin{array}{l}\text { Penicillin- } \\
\text { dihydrostreptomycin }\end{array}$ & $\begin{array}{l}\text { Orbeseal }+ \\
\text { penicillin- } \\
\text { dihydrostreptomycin }\end{array}$ & $\begin{array}{l}\text { Mixed linear } \\
\text { regression [accounted } \\
\text { for age, FCM, SCC } \\
\text { in previous lactation } \\
\text { and herd (random)] }\end{array}$ & $306 ; 2.71 \pm 0.10$ & $292 ; 2.32 \pm 0.10$ & 0.004 \\
\hline \multirow[t]{2}{*}{ Sanford et al. (2006b) } & Experiment 1 & Data & 7 & $500 \mathrm{mg}$ of cloxacillin & Orbeseal & $\begin{array}{l}\text { Mixed linear } \\
\text { regression [accounted } \\
\text { for age, SCC in } \\
\text { previous lactation } \\
\text { and herd (random)] }\end{array}$ & 1,$510 ; 2.59 \pm 0.10$ & $815 ; 2.53 \pm 0.12$ & 0.57 \\
\hline & Experiment 2 & & & & $\begin{array}{l}500 \mathrm{mg} \text { of cloxacillin } \\
+ \text { Orbeseal }\end{array}$ & & 1,$510 ; 2.59 \pm 0.10$ & $679 ; 2.74 \pm 0.13$ & 0.18 \\
\hline
\end{tabular}

$$
\begin{aligned}
& { }^{1} \text { SAS Institute Inc., Cary, NC } \\
& \text { 踣. } \quad \text { NA = not available. }
\end{aligned}
$$


Table 5. Analysis of linear score (LS) of individual cows in early lactation using a mixed effects linear regression model after adjusting for herd effects (random effects), parity, and LS at dry off (fixed effects) ${ }^{1}$

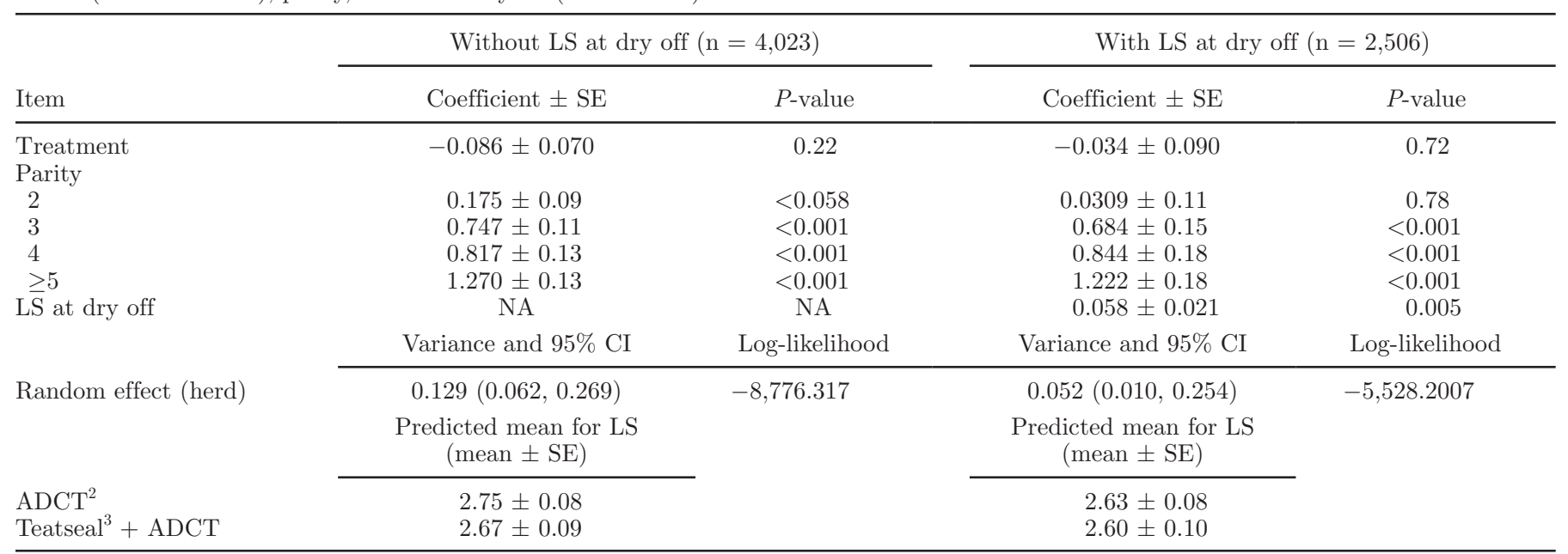

${ }^{1}$ Predicted means are detailed.

${ }^{2} \mathrm{ADCT}=$ antibiotic dry cow treatments.

${ }^{3}$ Pfizer Animal Health, West Ryde, Australia.

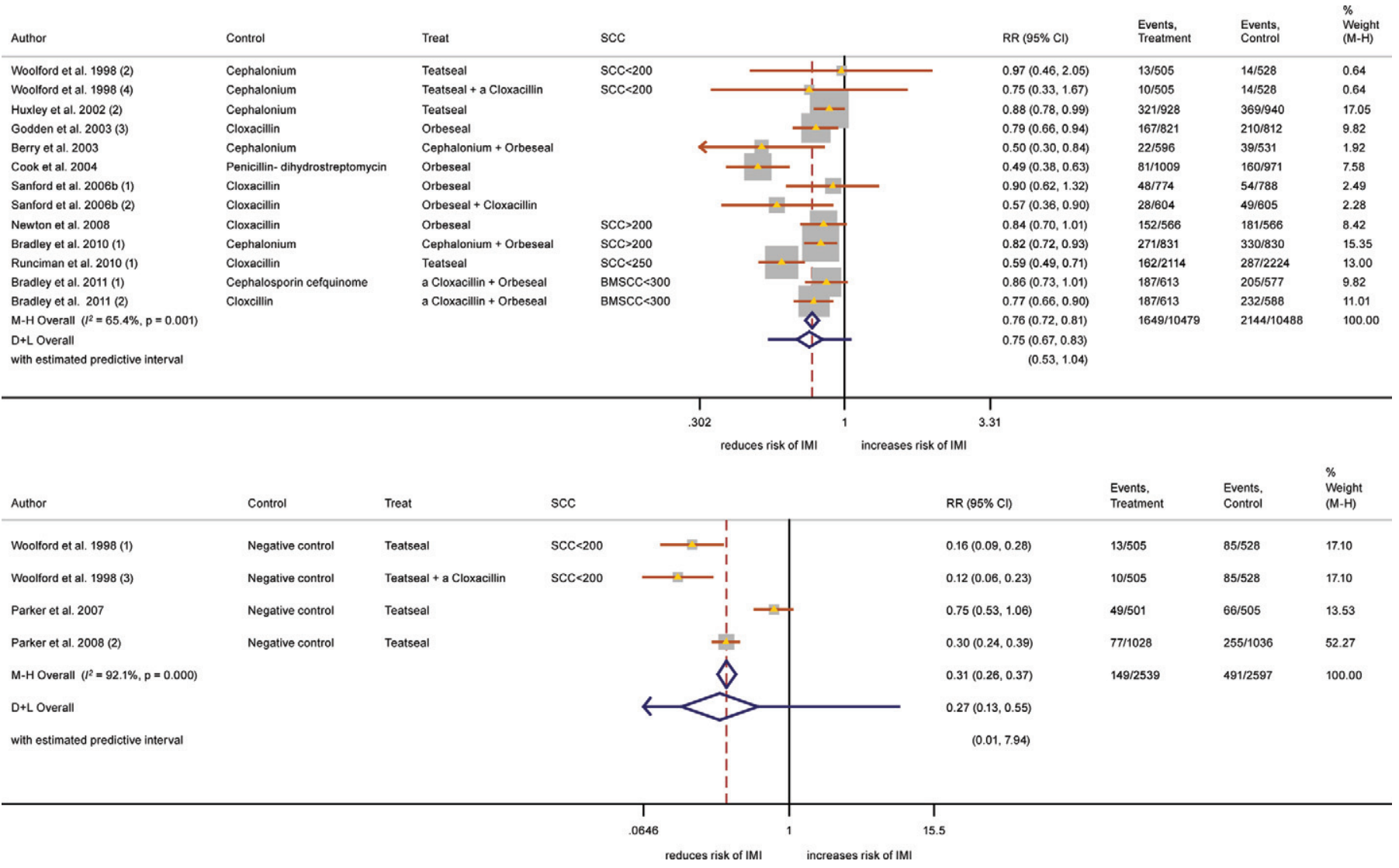

Figure 1. Forest plot of studies examining the risk of acquiring new IMI at the quarter level in lactating dairy cows treated with internal teat sealant compared with positive control (top) and negative control (bottom). Box sizes are proportional to the inverse variance of the estimates. Summary estimates of treatment effects (diamond shapes) are shown using (1) a fixed effects approach [M-H specifies a fixed effect model using the Mantel and Haenszel (1959) method], (2) a random effects approach [D+L specifies a random effects model using the method of DerSimonian and Laird (1986)], and (3) the predicted interval of a future trial, with the estimate of heterogeneity being taken from the inverse variance fixed effect model. $\mathrm{RR}=$ risk ratio; $\dot{I}^{2}=$ a statistic that describes the proportion of total variation in study effect estimates that is due to heterogeneity. Color version available in the online PDF. 
study separately (Table 4). The results were not significant, but the internal teat sealants + ADCT reduced the LS of milk SCC in 2 trials, but not in Sanford et al. (2006b; experiment 2). The LS of postpartum milk SCC data of 3 studies (Cook et al., 2005; Sanford et al., 2006b; Baillargeon and LeBlanc, 2010) were then pooled as 1 data set and analyzed using a mixed-effects linear model, in which herds within studies were used as a random effects term, to explore the effect of internal teat sealant in the presence of ADCT on LS (Table 5).

\section{RESULTS AND DISCUSSION}

Sufficient studies of suitable quality were identified to allow a meta-analysis to be conducted (Tables 1 and 2). Most experiments included in the published papers were conducted in multiple herds and several factors that could act to confound estimates of the effect of treatment were investigated by qualitative review and meta-regression to determine if the outcomes of these studies (IMI and clinical mastitis) may have been influenced by some of these factors.

\section{Random Allocation of Treatment Among Front and Rear Quarters Within Cow}

The probability of risk of infection among front and rear glands should be considered during the random allocation of treatments to different quarters within cow, as Adkinson et al. (1993) and Barkema et al. (1997) suggested that the risk of clinical mastitis is higher in the rear than front glands. If treatments were not applied equally across the front and rear glands or not accounted for, this could lead to a bias in assessing the efficacy of treatments. Berry et al. (2003), however, found no statistical differences in infection status at calving with respect to front or rear, or left or right quarters when cows were treated with ADCT or internal teat sealant (Orbeseal; Pfizer Ltd., Tadworth, UK). In all studies $(\mathrm{n}=6)$ that quarter within cows were the unit of observation and each quarter was treated with a different treatment regimen, the treatments were randomly allocated among the front and rear glands to avoid a potential bias.

\section{Between-Quarter Interdependence Within Cows}

Several studies $(\mathrm{n}=6)$ existed in which the quarters within a cow were allocated to different treatment regimens, such as ADCT, untreated (control), and treated with internal teat sealants with or without ADCT (Table 2). Concerns existed about the interdependence of quarters in studies that used different treatments at the quarter level within cow, as failure to account for interdependence of quarters within a cow may lead to inaccurate variance estimates and errors in assessing treatment effects. Berry et al. (2003) demonstrated that quarters that were untreated during the dry period were independent from treated quarters of the same cow with respect to the risk of an IMI at calving. Sanford et al. (2006a) studied whether intramammary half-udder infusion of cloxacillin resulted in transfer of cloxacillin from treated to untreated mammary gland quarters within nonlactating cows. This study also investigated the concentrations of antibiotic in quarters, and whether selection of ipsilateral versus diagonalcontralateral quarters for treatment affected cloxacillin transfer among quarters. Cloxacillin was detected in $25 \%$ of all untreated mammary gland quarters (Sanford et al., 2006a), but concentrations of cloxacillin in untreated quarters were below MIC for targeted mastitis pathogens. Their study also found significant differences in cloxacillin concentrations in the ipsilateral or diagonal treatment groups. The results of their study suggest that within-cow half-udder comparison trials are valid for antimicrobial trials in nonlactating cows, although transfer of antimicrobials does occur in trace concentrations (Sanford et al., 2006a).

Based on understandings derived from Berry et al. (2003) and Sanford et al. (2006a) regarding the random allocation and interdependence of quarters, we believe that the papers included in this meta-analysis have adequately addressed factors that may influence the validity of study designs.

\section{IMI}

A total of 12 studies with 17 subtrials, including 13 positive control subtrials and 4 negative control subtrials, on IMI were included in the analysis (Figure 1). Based on the considerations outlined above, the results are presented at the quarter level. The incidence of IMI reported includes the infected quarters that may have occurred during the dry period as well as those arising during and after calving. The use of internal teat sealants alone and in the presence of ADCT reduced the risk of acquiring new IMI after calving in lactating cows by $25 \%$ compared with the ADCT alone $(\mathrm{RR}=0.75$; 95\% CI: 0.67 to 0.83 ).

Treatment of cows with internal teat sealant alone [except in the study of Woolford et al. (1998), which was a combined treatment] reduced the risk of IMI by $73 \%$ of those in the untreated (negative control) cows $(\mathrm{RR}=0.23 ; 95 \% \mathrm{CI}: 0.13$ to 0.55$)$. The predictive interval estimates included 1.0 for the negative control studies (Figure 1), indicating that some null or negative responses to treatment with teat sealants may be observed in future studies. 


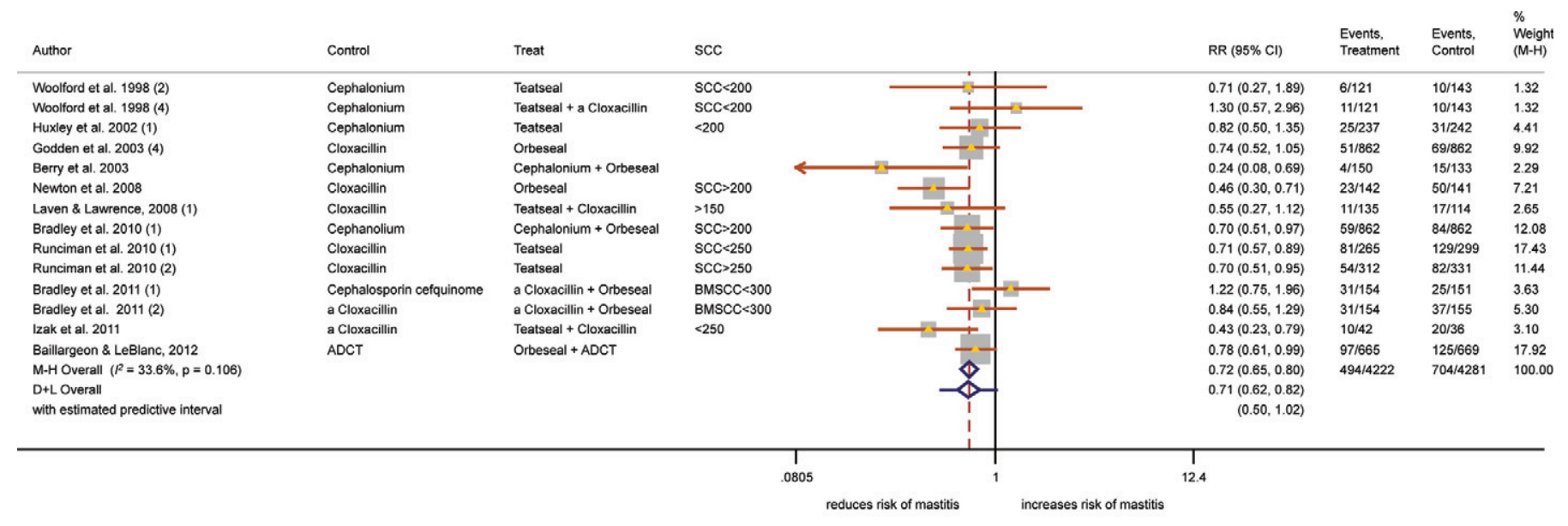

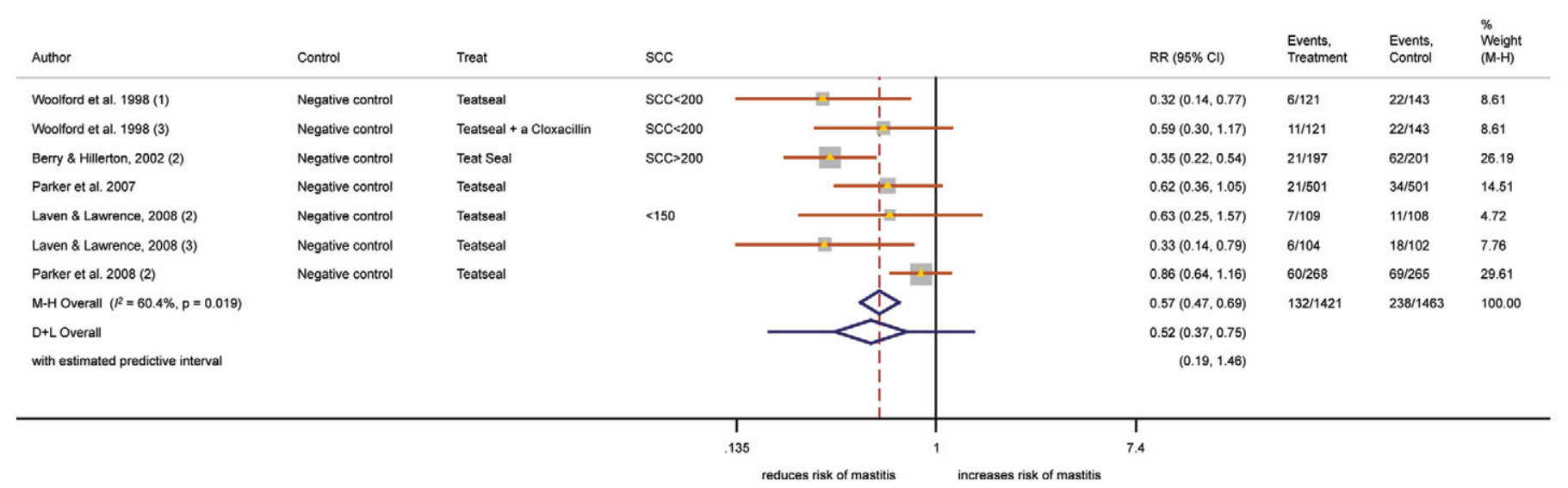

Figure 2. Forest plot of studies examining the risk of clinical mastitis up to 150 DIM at the cow and quarter levels in lactating dairy cows treated with internal teat sealant compared with positive control (top) and negative control (bottom). Box sizes are proportional to the inverse variance of the estimates. Summary estimates of treatment effects (diamond shapes) are shown using (1) a fixed effects approach [M-H specifies a fixed effect model using the Mantel and Haenszel (1959) method], (2) a random effects approach [D+L specifies a random effects model using the method of DerSimonian and Laird (1986)], and (3) the predicted interval of a future trial, with the estimate of heterogeneity being taken from the inverse variance fixed effect model. $\mathrm{RR}=$ risk ratio; $I^{2}=$ a statistic that describes the proportion of total variation in study effect estimates that is due to heterogeneity. Color version available in the online PDF.

Overall pooling of the study approaches (i.e., use of internal teat sealants alone or in the presence of ADCT) reduced the risk of IMI by $39 \%$ compared with cows treated with ADCT (positive control) and untreated (negative control) cows $(\mathrm{RR}=0.61 ; 95 \% \mathrm{CI}: 0.51$ to 0.72 ). However, given the marked differences in the pooled RR estimates between studies using teat sealants in the presence of ADCT and those without, we consider that the estimates of effect used in estimates of efficacy should be specific to whether teat sealant treatment is combined with ADCT or not.

The results of both meta-analyses of IMI, with positive and negative controls, were heterogeneous $\left(I^{2}=\right.$ $65.4 \%$ and $92.1 \% ; P<0.001$; Table 3 ). The sources of heterogeneity were explored, using the methods of Knapp and Hartung (2003) and Harbord and Higgins (2008), using variables for which we had sufficient data, including presence or absence of antibiotic in the control group, type of antibiotics used in control groups, infection status of cows before treatment, and location (country) of study. None of these factors significantly contributed to the heterogeneity of the results. We were unable to explore the effect of housing and farming systems on the IMI outcomes because the individual studies that were included in the analysis had pooled data from different farming and feeding systems into a single point estimate. The heterogeneity of results is not of great concern because all these studies showed the same direction toward a reduction in IMI $(R R<1)$. It is likely that differences in treatment protocols and the procedures used to detect the presence of IMI among studies contributed to the heterogeneity.

The NNT for each cow to benefit from the intervention is considered a useful, clinically meaningful way of reporting binary outcomes from randomized trials. For every 20 cows that were treated with the internal teat sealants in the presence of ADCT, 1 additional cow responded positively (i.e., did not have an IMI) to the 


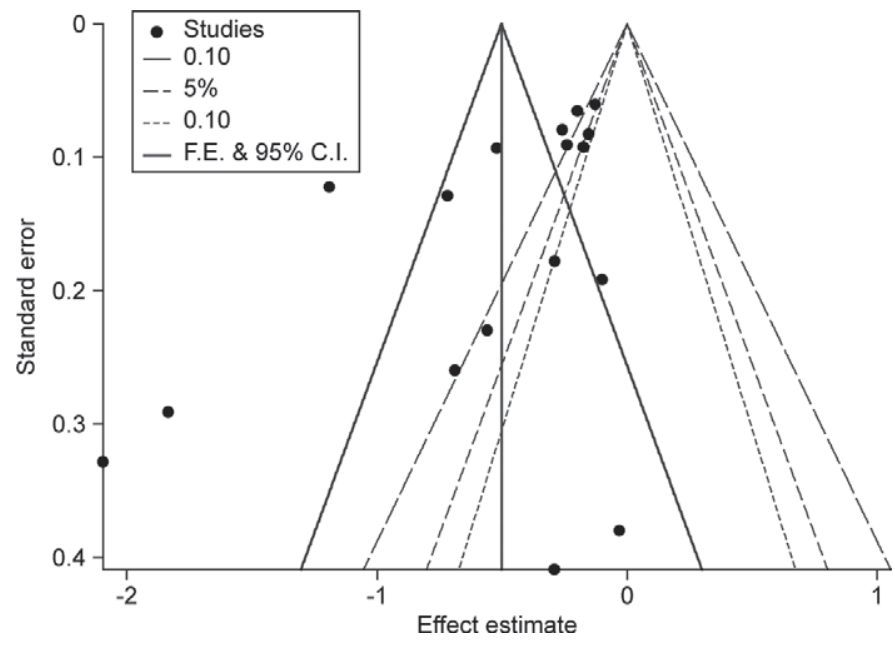

Figure 3. Contour-enhanced funnel plots of risk of IMI for lactating dairy cows treated with internal teat sealants with and without antibiotic. Legend: levels of significance for studies $(\bullet)$ within the broken lines are $0.01,0.05$, and $0.10 ; \mathrm{FE}=$ fixed effect.

combined treatment compared with ADCT treatment alone, whereas for every 7 cows that were treated with internal teat sealant in the presence of ADCT, the occurrence of 1 IMI was prevented compared with the untreated (negative control) cows.

\section{Clinical Mastitis}

A total of 16 studies with 21 subtrials, including 14 positive control subtrials and 7 negative control subtrials, on clinical mastitis up to 150 DIM were included in the analysis (Figure 2). The results were presented at both the quarter and cow levels. The incidence of

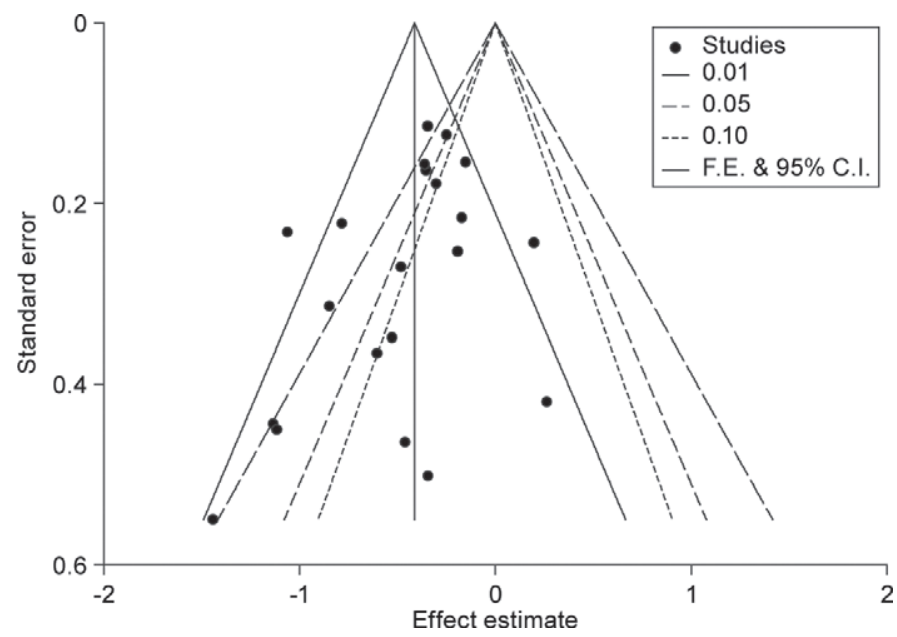

Figure 4. Contour-enhanced funnel plots of risk of clinical mastitis for lactating dairy cows treated with internal teat sealants with and without antibiotic. Legend: levels of significant for studies $(\bullet)$ within the broken lines are $0.01,0.05$, and $0.10 ; \mathrm{FE}=$ fixed effect. clinical mastitis includes clinical cases that occurred at calving and during the first 100 to 150 DIM.

The application of internal teat sealant products alone and in the presence of ADCT significantly reduced the risk of clinical mastitis after calving in lactating dairy cows (Table $3 ; P<0.001$ ). The use of internal teat sealants alone and in the presence of ADCT reduced the risk of clinical mastitis after calving in lactating cows by $29 \%$ compared with cows treated with ADCT alone $(\mathrm{RR}=0.71 ; 95 \%$ CI: 0.62 to 0.82$)$. Treatment of cows with internal teat sealants alone (Figure 3 ) reduced the risk of clinical mastitis by $48 \%(\mathrm{RR}=0.52 ; 95 \% \mathrm{CI}$ : 0.37 to 0.75 ) compared with the untreated cows (negative control). Overall, the use of internal teat sealants alone or in the presence of ADCT reduced the risk of clinical mastitis after calving by $34 \%(\mathrm{RR}=0.66 ; 95 \%$ CI: 0.58 to 0.76 ; Table 3). Again, marked differences existed in the pooled RR estimates between studies using teat sealants in the presence of ADCT and those without. Therefore, estimates of effect used should be specific to whether teat sealant treatment is combined with ADCT or not. Both analyses (i.e., the negative and the studies combined with ADCT) of the effects of teat sealants on clinical mastitis had the predictive intervals that included 1.0 (Figure 2), indicating that some null or negative responses to treatment with teat sealants may be observed in future studies.

The results of meta-analysis on clinical mastitis with positive controls were homogeneous $\left(I^{2}=33.6 \%\right.$; $P<$ $0.106)$, whereas the results of studies with negative controls were heterogeneous $\left(I^{2}=60.4 \% ; P<0.019\right)$, but the overall results were heterogeneous $\left(I^{2}=46.5 \%\right.$; $P<$ 0.001). We explored the source of heterogeneity, using the methods of Knapp and Hartung (2003) and Harbord and Higgins (2008), with the variables for which we had adequate data, including DIM, presence or absence of antibiotic in the control group, unit of treatment (quarters within cow vs. quarters between cows), type of antibiotic used in control groups, infection status of cows before treatment, and the location (country) where the study was conducted. None of these factors significantly contributed to the heterogeneity of the results.

Two studies (Woolford et al., 1998; Bradley et al., 2011) differed from other studies in the direction of effect. These studies compared the internal teat sealants in the presence of cloxacillin versus cows treated with cefquinome or cloxacillin (Bradley et al., 2011) and the risk of clinical mastitis in the internal teat sealants in the presence of cloxacillin was greater than the cefquinome (Figure 3). Bradley et al. (2011) suggested that cows in the cefquinome group were less likely to develop clinical mastitis than those in the cloxacillin-treated group. In Woolford et al. (1998), the unit of treatment was quarter within cow and the infected quarters with- 
in cows were allocated to the ADCT and combination of internal teat sealants and ADCT groups, whereas healthy quarters were allocated to negative and positive controls or internal teat sealants in the presence of ADCT. This difference in study design may explain the differences between the outcomes of their study compared with other studies. A sensitivity analysis was conducted by removing subtrial 2 of Woolford et al. (1998), but little change occurred in the overall point estimate $(\mathrm{RR}=0.65 ; 95 \% \mathrm{CI}: 0.57,0.75)$ and the results remained heterogeneous $\left(I^{2}=45.9 \% ; P=0.014\right)$.

The NNT analysis indicated that we need to treat 21 cows with internal teat sealant + ADCT to prevent 1 case of clinical mastitis compared with ADCT alone. When comparing the internal teat sealants + ADCT versus negative control (untreated), 13 cows needed to be treated to prevent an additional case of mastitis.

Sources of heterogeneity in these studies may include differences in the definition and diagnostic methods used for identifying clinical mastitis. Again, we could not explore the effects of housing and farming systems on clinical mastitis, because individual studies pooled data from different farming and feeding systems into a single point estimate.

Although no robust statistical test exists to precisely quantify the presence or absence of publication bias in a meta-analysis, funnel plots are used to evaluate the presence or absence of publication bias. We used contour-enhanced plots to differentiate between the highly significant trails and the other studies as proposed by Peters et al. (2008). The contour-enhanced funnel plots of IMI and clinical mastitis showed some evidence of publication bias (Figures 3 and 4). The probability of publication of studies with results showing a reduction in the number clinical mastitis cows in treatment group was greater than studies that reported an increase in the number of clinically mastitic cows. The point estimates on the very left side of the funnel plot may indicate highly significant reductions $(P<0.01)$ in the probability of IMI and clinical mastitis in dairy cows treated with teat sealant, rather than publication bias.

\section{Milk SCC}

Three studies reported LS of milk SCC data after calving (Godden et al., 2003; Baillargeon and LeBlanc, 2010; Runciman et al., 2010). Godden et al. (2003) demonstrated that quarters treated with Orbeseal and cloxacillin had a significantly lower mean LS at both 1 to 3 DIM and 6 to 8 DIM than control, cloxacillin only, quarters (Table 4; $P<0.001$ ). An Australian study (Runciman et al., 2010) also showed that the mean LS for the cows treated with Teatseal and cloxacillin was significantly lower compared with cows treated with cloxacillin (Table 5; $P<0.001$ ) after accounting for herd, age, milk production and SCC status in previous lactation. However, Baillargeon and LeBlanc (2010) found no significant reduction between ADCT and Teatseal and ADCT combined groups (Table 4; $P=$ $0.11)$ across several herds.

The analysis of pooled LS data, before and after controlling for LS at drying off, showed that no significant differences in LS existed between cows treated with internal teat sealants + ADCT versus ADCT alone. The interaction between LS at drying off and treatments was also not statistically significant. These limited data suggest that the effect of internal teat sealants $+\mathrm{ADCT}$ on postpartum milk SCC deserves further study.

\section{CONCLUSIONS}

The application of internal teat sealants with or without ADCT at dry off significantly reduced the incidence of IMI and clinical mastitis in lactating dairy cows. Further studies are needed to investigate the effect of internal teat sealants on milk SCC in lactating dairy cows after calving. Further clinical trials may provide further evidence of effects of treatment on this outcome.

\section{ACKNOWLEDGMENTS}

This study was funded and supported by Zoetis (formerly Pfizer Animal Health, West Ryde, Australia). We thank the authors of papers who generously provided their raw data and helped with the analysis of milk SCC data. The technical advice on the statistical analysis of SCC that was provided by Ian Dohoo (University of Prince Edward Island, Charlottetown, $\mathrm{PE}$, Canada) is greatly appreciated.

\section{REFERENCES}

Adkinson, R. W., K. H. Ingawa, D. C. Blouin, and S. C. Nickerson. 1993. Distribution of clinical mastitis among quarters of the bovine udder. J. Dairy Sci. 76:3453-3459.

Baillargeon, P., and S. J. LeBlanc. 2010. Clinical and economic effects of an internal teat sealant at dry-off on the incidence of clinical mastitis in early lactation. Bovine Pract. 44:1-11.

Barkema, H. W., Y. H. Schukken, T. J. Lam, D. T. Galligan, M. L. Beiboer, and A. Brand. 1997. Estimation of interdependence among quarters of the bovine udder with subclinical mastitis and implications for analysis. J. Dairy Sci. 80:1592-1599.

Begg, C. B., and M. Mazumdar. 1994. Operating characteristics of a rank correlation test for publication bias. Biometrics 50:1088-1101.

Berry, E. A., and J. E. Hillerton. 2002a. The effect of an intramammary teat seal on new intramammary infections. J. Dairy Sci. 85:2512-2520.

Berry, E. A., and J. E. Hillerton. 2002b. The effect of selective dry cow treatment on new intramamamry infections. J. Dairy Sci. $85: 112-121$.

Berry, E. A., and J. E. Hillerton. 2007. Effect of an intramammary teat seal and dry cow antibiotic in relation to dry period length on postpartum mastitis. J. Dairy Sci. 90:760-765.

Berry, E. A., W. T. Johnston, and J. E. Hillerton. 2003. Prophylactic effects of two selective dry cow strategies accounting for interdependence of quarter. J. Dairy Sci. 86:3912-3919. 
Bradburn, M. J. 2003. Updated and new commands for meta-analysis in Stata. Accessed March 2013. http://wenku.baidu.com/ view/8dcb3aa20029bd64783e2c1c.html.

Bradburn, M. J., J. J. Deeks, and D. G. Altman. 1998. sbe24. metanAn alternative meta-analysis command. Stata Tech. Bull. 44:415.

Bradley, A. J. 2002. Bovine mastitis: An evolving disease. Vet. J. 164:116-128.

Bradley, A. J., J. E. Breen, B. Payne, P. Williams, and M. J. Green. 2010. The use of a cephalonium containing dry cow therapy and an internal teat sealant, both alone and in combination. J. Dairy Sci. 93:1566-1577.

Bradley, A. J., J. E. Breen, B. Payne, P. Williams, and M. J. Green. 2011. A comparison of broad-spectrum and narrow-spectrum dry cow therapy used alone and in combination with a teat sealant. J. Dairy Sci. 94:692-704

Bramley, A. J., and F. H. Dodd. 1984. Reviews of the progress of dairy science: Mastitis control-Progress and prospects. J. Dairy Res. $51: 481-512$.

Browning, J. W., G. A. Mein, M. Barton, T. J. Nicholls, and P. Brightling. 1990. Effects of antibiotic therapy at drying off on mastitis in the dry period and early lactation. Aust. Vet. J. 67:440-442.

Cook, N. B., D. A. Pionek, and P. Sharp. 2005. An assessment of the benefits of Orbeseal ${ }^{\circledR}$ when used in combination with dry cow antibiotic therapy in three commercial dairy herds. Bovine Pract. 39:83-94

Crispie, F., J. Flynn, R. P. Ross, C. Hill, and W. J. Meaney. 2004. Dry cow therapy with a non-antibiotic intramammary teat seal-A review. Ir. Vet. J. 57:412-418.

DerSimonian, R., and N. Laird. 1986. Meta-analysis in clinical trials. Control. Clin. Trials 7:177-188.

Egger, M., and G. Davey Smith. 2001. Principles of and procedures for systematic reviews. Pages 23-42 in Systematic Reviews in Health Care: Meta-Analysis in Context. M. Egger, G. Davey Smith, and D. G. Altman, ed. British Medical Journal Books, London, UK.

Egger, M., G. D. Davey Smith, and D. G. Altman. 2001. Systematic Reviews in Health Care: Meta-Analysis in Context. British Medical Journal Books, London, UK.

Egger, M., G. Davey Smith, M. Schneider, and C. Minder. 1997. Bias in meta-analysis detected by a simple, graphical test. BMJ 315:629-634.

Godden, S., P. Rapnicki, S. Stewart, A. Fetrow, A. Johnson, R. Bey, and R. Farnsworth. 2003. Effectiveness of an internal teat seal in the prevention of new intramammary infections during the dry and early-lactation periods in dairy cows when used with a dry cow intramammary antibiotic. J. Dairy Sci. 86:3899-3911.

Harbord, R. M., and J. P. T. Higgins. 2008. Meta-regression in Stata. Stata J. 8:493-519.

Higgins, J. P. T., and S. G. Thompson. 2002. Quantifying heterogeneity in a meta-analysis. Stat. Med. 21:1539-1558.

Higgins, J. P. T., S. G. Thompson, J. J. Deeks, and D. G. Altman. 2003. Measuring inconsistency in meta-analysis. BMJ 327:557560.

Huxley, J. N., M. J. Green, L. E. Green, and A. J. Bradley. 2002. Evaluation of the efficacy of an internal teat sealer during the dry period. J. Dairy Sci. 85:551-561.

Izak, E., and S. Ackermann. 2010. Prevalence and incidence of clinical mastitis at early lactation in dairy farms with low bulk tank somatic cell count in Argentina. Pages 266-267 in Proc. 49th Annual Meeting of the National Mastitis Council. National Mastitis Council, Verona, WI.

Izak, E., E. Castello, and G. Veneranda. 2011. Efficacy and economic benefit of an internal teat sealant during drought and rainy weather dry period on incidence of clinical mastitis. In 3rd International Symposium on Mastitis and Milk Quality, St. Louis, MO. American Association of Bovine Practitioners, Auburn, AL; and National Mastitis Council, Verona, WI.

Knapp, G., and J. Hartung. 2003. Improved tests for a random-effects meta-regression with a single covariate. Stat. Med. 22:2693-2710.

Laven, R. A., and K. E. Lawrence. 2008. Efficacy of blanket treatment of cow and heifers with internal teat sealant reducing the risk of mastitis in dairy cattle calving on pasture. N. Z. Vet. J $56: 171-175$

Lean, I. J., P. Celi, H. Raadsma, J. P. McNamara, and A. R. Rabiee. 2012. Effects of dietary crude protein on fertility: Meta-analysis and meta-regression. Anim. Feed Sci. Technol. 171:31-42.

Mantel, N., and W. Haenszel. 1959. Statistical aspects of the analysis of data from retrospective studies of disease. J. Natl. Cancer Inst. $22: 719-748$.

Meaney, W. J. 1977. Effect of a dry period teat seal on bovine udder infection. Isr. J. Agric. Res. 16:293-299.

Newton, H. T., M. J. Green, H. Benchaoui, V. Cracknell, T. Rowan, and A. J. Bradley. 2008. Comparison of the efficacy of cloxacillin alone and cloxacillin combined with an internal teat sealant for dry-cow therapy. Vet. Rec. 162:678-684.

Oliver, S. P., and S. E. Murinda. 2012. Antimicrobial resistance of mastitis pathogens. Vet. Clin. North Am. Food Anim. Pract. $28: 165-185$.

Parker, K. I., C. Compton, F. M. Anniss, A. Weir, C. Heuer, and S. McDougall. 2007. Subclinical and clinical mastitis in heifers following the use of a teat sealant precalving. J. Dairy Sci. 90:207-218.

Parker, K. I., C. Compton, F. M. Anniss, A. Weir, C. Heuer, and S. McDougll. 2008. Quarter-level analysis of subclinical and clinical mastitis in primiparous heifers following the use of a teat sealant or an injectable antibiotic, or both, precalving. J. Dairy Sci. 91:169-181.

Peters, J. L., A. J. Sutton, D. R. Jones, K. R. Abrams, and L. Rushton. 2008. Contour enhanced meta-analysis funnel plots help distinguish publication bias from other causes of asymmetry. J. Clin. Epidemiol. 61:991-996.

Rabiee, A. R., K. Breinhild, W. Scott, H. M. Golder, E. Block, and I. J. Lean. 2012. Effect of fat additions to diets of dairy cattle on milk production and components: A meta-analysis and metaregression. J. Dairy Sci. 95:3225-3247.

Rothman, K. J. 1986. Modern Epidemiology. Little, Brown and Company, Boston, MA.

Ruegg, P. L. 2012. Mastitis in dairy cows. Vet. Clin. North Am. Food Anim. Pract. 28:xi-xii

Runciman, D. J., J. Malmo, and M. Deighton. 2010. The use of an internal teat sealant in combination with cloxacillin dry cow therapy for the prevention of clinical and subclinical mastitis in seasonal calving dairy cows. J. Dairy Sci. 93:4582-4591.

Sanford, C. J., G. P. Keefe, I. R. Dohoo, and K. E. Leslie. 2006a. Assessment of antimicrobial transfer from treated to untreated mammary gland quarters by use of high-pressure liquid chromatography for detection of cloxacillin in milk samples from nonlactating dairy cows. Am. J. Vet. Res. 67:1140-1144.

Sanford, C. J., G. P. Keefe, I. R. Dohoo, K. E. Leslie, R. T. Dingwell, L. DesCôteaux, and H. W. Barkema. 2006b. Efficacy of using an internal teat sealer to prevent new intramammary infections in nonlactating dairy cattle. J. Am. Vet. Med. Assoc. 228:15651573 .

StataCorp. 2011. Stata Statistical Software: Release 12. StataCorp LP, College Station, TX.

Thompson, S. G., and S. J. Sharp. 1999. Explaining heterogeneity in meta-analysis: A comparison of the methods. Stat. Med. 18:26932708 .

Watts, J. L. 1988. Etiological agents of bovine mastitis. Vet. Microbiol. 16:41-66.

WHO (World Health Organization). 1994. Scientific Working Group on Monitoring and Management of Bacterial Resistance to Antimicrobial Agents. WHO, Geneva, Switzerland.

Williamson, J. H., M. W. Woolford, and A. M. Day. 1995. The prophylactic effect of a dry cow antibiotic against Streptococcus uberis. N. Z. Vet. J. 43:228-234.

Woolford, M. W., J. H. Williamson, A. M. Day, and P. J. A. Copeman. 1998. The prophylactic effect of a teat sealer on bovine mastitis during the dry period and the following lactation. N. Z. Vet. J. $46: 12-19$. 
Table A1. Definitions of IMI and clinical mastitis (CM) used by the study investigators

Reference Definitions of IMI and CM

Bradley et al. (2010, 2011)

Bradley et al. (2011)

Runciman et al. (2010)

Woolford et al. (1998)

Godden et al. (2003)

Berry and Hillerton (2002a, 2007)

Newton et al. (2008)

Cook et al. (2005)

Huxley et al. (2002)

Laven and Lawrence (2008)

Parker et al. (2007)

Parker et al. (2008)

Sanford et al. (2006b)

Izak et al. (2011)

Baillargeon and LeBlanc (2010)
IMI: isolation of an organism was considered indicative of an IMI

CM: farm personnel trained in the detection and sampling of CM throughout the study period $(\leq 150$ DIM)

IMI: new IMI was defined as the presence of a pathogen in the postcalving sample that had not been present at sampling at drying off

CM: farm personnel trained in the detection and sampling of CM throughout the study period $(\leq 150$ DIM)

IMI: presence of clotted or discolored milk beyond the first 3 squirts of milk when the suspected quarter was hand stripped, or a hot or swollen quarter, or both

IMI: during the lactation (last $7 \mathrm{~d}$ ) and after calving, milk samples were collected for bacteriological examination and detection of IMI

CM: during the dry period, udder examination was conducted, which involved palpation of individual quarters to detect any difference in tissue firmness between adjacent quarters and hence the presence of clinical IMI; quarters determined to be clinically infected by palpation were sampled for bacteriological culture up to 150 DIM

Not provided

IMI: pathogen is isolated in 2 consecutive samples ( 2 out of 3 samples), or a pathogen obtained from 1 milk sample with elevated SCC in comparison with other quarter SCC

CM: CM cases were detected by farm staff or at routine sampling time. These were defined when visible changes in the milk, such as watery milk, clots or flakes, or changes in the udder such as swelling or heat, were observed

CM: CM was defined as the presence of an abnormal secretion or udder changes, or both (heat pain or swelling, or both) as diagnosed by the herdsperson

Clinical cases of mastitis were identified by herdspersons and milk samples were collected for bacteriological examination

A minor pathogen was defined as either a coagulase-negative Staphylococcus species or a Corynebacterium species

IMI: new dry period infection: a significant isolate of an organism found in a quarter at the 1 to 3 DIM sample that was not present in the quarter sample at dry off

Dry period cure: absence of an organism in a quarter at the 1 to 3 DIM sample that was present at dry off

CM: quarter case of mastitis: a mastitis event in a single quarter; repeat cases occurring in the same quarter were considered a new clinical quarter case if the interval between events exceeded $7 \mathrm{~d}$

CM: cow case of mastitis: a cow suffering mastitis in 1 or more quarters at the same time; repeat cow cases were considered a new cow case if the interval between events exceeded $7 \mathrm{~d}$

Diagnosis, grading, and sampling of CM was conducted by trained herdspersons

CM: CM quarter case: a single recorded occurrence of CM in a quarter, including all multiple quarter and recurrent cases; recurrent cases were classified as cases recurring in the same quarter greater than 5 $\mathrm{d}$ after the end of the last clinical episode and caused by the same pathogen

CM: CM cow case: a cow experiencing a mastitis event, regardless of the number of quarters affected or the number of times each quarter was affected (if caused by the same pathogen)

CM: diagnosis of CM was performed by a farmer and was based on the presence of clots in the milk, or of swelling, heat, or pain of the udder

CM: CM was defined as the presence of grossly visible changes (e.g., clots or blood) in the milk composition or swelling, pain, or both, in the gland; herd owners collected duplicate milk samples from glands diagnosed with $\mathrm{CM}$

CM: CM was diagnosed by the herd owner based on the presence of visible changes (e.g., clots or discoloration) in the milk or swelling/pain in the gland

IMI: IMI was defined as isolation of any major mastitis-causing organism in conjunction with an SCC $>200,000$ cells $/ \mathrm{mL}$, or isolation of CNS (>10 cfu/0.01 mL of milk) in conjunction with an SCC $>200,000$ cells $/ \mathrm{mL}$

CM: CM was defined as abnormal milk with or without signs of heat, redness, or swelling in the quarter and with or without clinical signs of systemic disease

CM: CM was defined as the presence of visibly abnormal milk and (or) abnormal quarter or signs of systemic illness; isolates were identified according to the procedures of the National Mastitis Council (Izak and Ackermann, 2010)

CM: CM was defined as the presence of visibly abnormal milk (e.g., presence of clots, watery secretion) beyond the third forestripping, with or without signs of abnormality in the quarter or signs of systemic disease; following the clinical diagnosis, milk samples from the affected quarters were collected by producers 
Table A2. Studies that investigated the effect of internal teat sealants (Teatseal and Orbeseal; Pfizer Animal Health, West Ryde, Australia) on the incidence of IMI and clinical mastitis during the dry period and after calving

\begin{tabular}{|c|c|c|c|c|}
\hline Study & Country & Milk sampling interval & $\begin{array}{l}\text { Diagnosis description } \\
\text { and procedures }\end{array}$ & Housing/farming \\
\hline Bradley et al. (2010) & United Kingdom & Prior to final milking and postcalving & $\begin{array}{l}\text { Bacteriological examination } \\
\text { postcalving; clinical cases until } 150\end{array}$ & $\begin{array}{l}\text { Freestalls, covered straw } \\
\text { yards, pasture }\end{array}$ \\
\hline Bradley et al. (2011) & United Kingdom & Prior to final milking and postcalving & $\begin{array}{l}\text { Bacteriological examination } 2 \mathrm{wk} \\
\text { precalving; clinical cases until } 150 \text { DIM }\end{array}$ & $\begin{array}{l}\text { Freestalls, covered straw } \\
\text { yards, pasture (combination } \\
\text { of all) }\end{array}$ \\
\hline Runciman et al. (2010) & Australia & $\begin{array}{l}\text { Postcalving milk samples (d 21, 30, and } \\
100)\end{array}$ & $\begin{array}{l}\text { Clinical examination and then } \\
\text { bacteriological tests of quarters }\end{array}$ & Pasture $(\mathrm{n}=6)$ \\
\hline Woolford et al. (1998) & New Zealand & $\begin{array}{l}\text { Within } 7 \mathrm{~d} \text { of last lactation and within } 24 \mathrm{~h} \\
\text { after calving }\end{array}$ & $\begin{array}{l}\text { Clinical examination and } \\
\text { bacteriological tests }\end{array}$ & Pasture $(\mathrm{n}=3)$ \\
\hline Godden et al. (2003) & United States & $\begin{array}{l}\text { Immediately before final milking, } 1 \text { to } 3 \\
\text { DIM and } 6 \text { to } 8 \text { DIM }\end{array}$ & $\begin{array}{l}\text { Bacteriological tests at dry off, dry off } \\
\text { and } 1 \text { to } 3 \text { DIM, dry off and } 6 \text { and } 8 \\
\text { DIM, and then up to } 60 \text { DIM }\end{array}$ & $\begin{array}{l}\text { Paddock (grazing) before } \\
\text { dry off, and then freestall } \\
\text { during experiment }(\mathrm{n}=2)\end{array}$ \\
\hline Berry and Hillerton (2002a) & United Kingdom & $\begin{array}{l}\text { One week before drying off, at drying off, at } \\
\text { calving, and } 1 \text { wk after calving }\end{array}$ & $\begin{array}{l}\text { Bacteriological tests at } 1 \text { wk before dry } \\
\text { off, at dry off, at calving, } 7 \text { DIM, and } \\
\text { clinical observation by farm staff until } \\
150 \text { DIM }\end{array}$ & $\begin{array}{l}\text { Organic farms }(\mathrm{n}=2) \text { and } \\
\text { research farms }(\mathrm{n}=2)\end{array}$ \\
\hline Berry et al. (2003) & United Kingdom & $\begin{array}{l}\text { One week before drying off, at drying off, at } \\
\text { calving, and } 1 \text { wk after calving }\end{array}$ & $\begin{array}{l}\text { Bacteriological tests at } 1 \text { wk before dry } \\
\text { off, at dry off, at calving, } 7 \text { DIM, and } \\
\text { clinical observation by farm staff until } \\
150 \text { DIM }\end{array}$ & Research farm $(\mathrm{n}=1)$ \\
\hline Newton et al. (2008) & United Kingdom & $\begin{array}{l}\text { Two days before drying off, } 1 \mathrm{~d} \text { before } \\
\text { drying off, at drying off, } 4 \mathrm{~d} \text { after calving, } \\
\text { and } 8 \text { to } 11 \mathrm{~d} \text { after calving }\end{array}$ & $\begin{array}{l}\text { Bacteriological tests at } 2 \mathrm{~d} \text { before } \\
\text { drying off, } 1 \mathrm{~d} \text { before drying off, on the } \\
\text { day of drying off, } 4 \text { DIM, and between } \\
8 \text { and } 10 \text { DIM }\end{array}$ & \\
\hline Cook et al. (2005) & USA & Prior to drying off and within $3 \mathrm{~d}$ of calving & $\begin{array}{l}\text { Bacteriological tests at dry off, within } \\
3 \mathrm{~d} \text { of calving, and on clinical cases up } \\
\text { to } 150 \text { DIM }\end{array}$ & $\begin{array}{l}\text { Freestall (rubber matt }= \\
1 ; \text { sand bedded }=1 ; \text { straw } \\
\text { bedded }=1 \text { ) }\end{array}$ \\
\hline Huxley et al. (2002) & United Kingdom & $\begin{array}{l}\text { Prior to drying off and after calving before } \\
\text { the first machine milking }\end{array}$ & $\begin{array}{l}\text { Bacteriological tests at dry off, after } \\
\text { calving, and before first milking }\end{array}$ & $\begin{array}{l}\text { Pasture (summer) and } \\
\text { covered stalls (winter) }\end{array}$ \\
\hline Laven and Lawrence (2008) & New Zealand & Not provided & Clinical diagnosis by farmer & Grazing $(\mathrm{n}=1)$ \\
\hline Parker et al. (2007) & New Zealand & Prior to treatment and within $4 \mathrm{~d}$ of calving & $\begin{array}{l}\text { Bacteriological tests at } 31 \text { d before } \\
\text { calving start date, } 4 \text { DIM, and clinical } \\
\text { diagnosis from calving to } 14 \text { DIM }\end{array}$ & Grazing $(\mathrm{n}=5)$ \\
\hline Parker et al. (2008) & New Zealand & Prior to treatment and within $5 \mathrm{~d}$ of calving & $\begin{array}{l}\text { Bacteriological tests at } 31 \mathrm{~d} \text { before } \\
\text { calving start date, and clinical } \\
\text { diagnosis from calving to } 14 \text { DIM }\end{array}$ & Grazing $(\mathrm{n}=30)$ \\
\hline Sanford et al. (2006b) & Canada & $\begin{array}{l}\text { Two weeks before calving and within } 8 \mathrm{~d} \\
\text { after calving }\end{array}$ & $\begin{array}{l}\text { Bacteriological tests at } 14 \mathrm{~d} \text { before dry } \\
\text { off, end of lactation, within } 8 \text { DIM, } \\
\text { and } 60 \text { DIM on cows with clinical signs }\end{array}$ & $\begin{array}{l}\text { Freestall }(\mathrm{n}=8) ; \text { tie-stall } \\
(\mathrm{n}=8)\end{array}$ \\
\hline Izak et al. (2011; abstract) & Argentina & Not provided & $\begin{array}{l}\text { Bacteriological tests from calving to } 10 \\
\text { DIM and at } 150 \text { DIM }\end{array}$ & \\
\hline Baillargeon and LeBlanc (2010) & Canada & Postcalving mastitic cows were sampled & $\begin{array}{l}\text { Bacteriological tests on clinical } \\
\text { mastitis cases up to } 105 \text { DIM }\end{array}$ & $\begin{array}{l}\text { Freestall }(\mathrm{n}=7) ; \text { tie-stall } \\
(\mathrm{n}=5)\end{array}$ \\
\hline
\end{tabular}

